\title{
TIME LIMITS ON WELFARE USE UNDER INVOLUNTARY UNEMPLOYMENT
}

\author{
CHRISTIAN HOLZNER \\ VOLKER MEIER \\ MARTIN WERDING
}

\author{
CESIFo Working PAPER No. 1220 \\ CATEgory 3: Social Protection \\ JUNE 2004
}

\footnotetext{
An electronic version of the paper may be downloaded

- from the SSRN website: www.SSRN.com

- from the CESifo website: www.CESifo.de
} 


\title{
Time Limits on Welfare Use under Involuntary Unemployment
}

\begin{abstract}
The impacts of introducing or tightening time limits on welfare use are studied in an efficiency wage model. Those losing access to regular benefits receive some smaller benefit, which can be interpreted as food stamps. Stricter time limits raise both employment and profits and generally reduce the tax rate. The impact on the net wage is ambiguous. Changes of utility levels of employed workers and recipients of regular social assistance have the same sign as the variation in the net wage. The utility differential between social assistance recipients and food stamp participants shrinks.
\end{abstract}

JEL Classification: H53, J41, J60.

Keywords: welfare benefits, time limits, efficiency wages.

Christian Holzner

Ifo Institute for Economic Research
at the University of Munich
Poschingerstr.5
81679 Munich
Germany
holzner@ifo.de

Volker Meier

Ifo Institute for Economic Research at the University of Munich

Poschingerstr. 5

81679 Munich

Germany

meier@ifo.de

\author{
Martin Werding \\ Ifo Institute for Economic Research \\ at the University of Munich \\ Poschingerstr. 5 \\ 81679 Munich \\ Germany \\ werding@ifo.de
}

We would like to thank the German Research Foundation for financial support under grant No. WE 2815/1-1. 


\section{Introduction}

The last decade has witnessed a renewed interest in redesigning welfare programs. Observing strong increases in the number of recipients during the eighties and nineties, many states in the U.S. have started "welfare to work" reforms. One of the main features is that time limits for welfare recipients have been introduced. According to the Personal Responsibility and Work Opportunity Reconcilation Act (PRWORA), nobody is eligible for receiving welfare payments based on the federal Temporary Assistance for Needy Families (TANF) program for more than five years in lifetime and two years per spell. Should time run out, there is no further access to federal cash benefits, but only to some state-financed food stamp program in order to guarantee physical subsistence. Data from the National Longitudinal Survey of Youth and simulation results by Gittleman (1999) referring to the older Aid to Families with Dependent Children (AFDC) program suggest that prior to TANF around a quarter of all welfare recipients were at risk of hitting the five year limit. Using data on AFDC taken from the Panel Study of Income Dynamics, Duncan et al. (2000) estimate that 41 per cent of the welfare caseload existing at a given point in time would reach the five year limit within eight years.

In addition to the time limits on welfare eligibility, work requirements have often been introduced. Unemployment may thus decrease as welfare recipients are forced in several ways to increase their job search efforts. Indeed, the number of welfare recipients in the U.S. has fallen drastically from 5.1 million families in March 1994 to 2.1 million families in March 2001 (Hotz et al., 2002). Surveys of the details of the U.S. welfare reform and problems of implementing them in practice have been provided by Ellwood (2000), Haveman and Wolfe (2000), Moffitt (2002), and Blank (2002).

This paper focuses on the impact of introducing time limits on welfare use on employment, wages, profits, and utility levels of both employed and unemployed workers. In contrast to the bulk of the literature, which mainly addresses incentives for labor supply, a framework with involuntary unemployment is chosen. The contribution can be seen as 
complementing earlier analyses in which the success of welfare reform depends on changes of the behavior of recipients. If jobs are easily available, the reason for potential employment increases is straightforward. Welfare recipients will reduce their reservation wages when faced with a cut in their income. Under involuntary unemployment, labor demand will respond to changes in the incentive structure of the employed who see unemployment as a more severe threat now. New job opportunities are created affecting the well-being: of forward-looking welfare recipients. This may compensate them for the time limits imposed.

Some evidence that the decline in caseloads is actually driven by labor demand can also be found in the empirical literature. For example, Ziliak et al. (2000) estimate that about two thirds of the caseload decline in the AFDC program between 1993 and 1996 is explained by macroeconomic factors represented, e.g., by lower unemployment rates. Only one third can be attributed to several regional welfare reforms adopted in various states. Similarly, Arulampalam and Stewart (1995) find for the UK that the effect of unemployment income on the individual hazard rate to exit unemployment is substantially lower in periods of high unemployment, while demand-side factors captured by the local unemployment rate have a strong negative effect on the exit probability. Hence, an analysis on the effects of welfare reform is needed for a framework in which labor demand plays a decisive role while search efforts are of secondary importance or even irrelevant. In the light of our approach, the fall in unemployment in the U.S. should not be viewed as indicating some exogenous business cycle phenomenon. It may at least partially be traced back to stricter welfare eligibility rules that enable firms to cut wages.

We analyze an efficiency wage model where workers may shirk. Since unemployment insurance is neglected, all unemployed become recipients of social assistance or food stamps. Both branches of welfare are financed by a proportional income tax. All individuals are identical with respect to ability and preferences.

It is shown that imposing a stricter time limit on receiving social assistance increases 
employment. By making unemployment less comfortable, employers can cut gross wages and raise employment without having to fear that workers lose their incentive to exert effort. In addition, a lower tax rate due to having to pay smaller benefits per welfare recipient represents a second channel that enables firms to pay lower gross wages and to hire additional workers. With a smaller number of unemployed, the tax load tends to fall. Since the average duration of unemployment falls with an increasing employment level, the share of those receiving the full benefit may go in either direction. The increasing fraction of social assistance recipients among the unemployed due to a higher employment level works against a tax cut. Net profits will generally rise due to falling gross wages and a lower tax rate. The impact on net wages is ambiguous. Fxpected lifetime utility levels of employed and social assistance recipients will move in the same direction as net wages. The utility differential between the two groups remains constant because it is determined by the structure of incentives for employed workers. Recipients of social assistance are compensated for the risk of losing parts of the welfare benefit by improved job opportunities. Those who would be on food stamps anyway may win in utility even if the net wage declines since their prospects of getting a job are improved. The result indicates that imposing stricter time limits can even lead to a Pareto improvement.

The distributional results tend to carry through if firms discriminate against food stamp recipients when making hiring decisions. Since a higher share of food stamp recipients at a given employment level then raises reemployment probabilities of an unemployed of a given group, it is no longer obvious that unemployment becomes more threatening, however.

Note that, since the focus of the model is on time limits per unemployment spell, the structure of benefits resembles a two-tier system of unemployment pay. Therefore, our contribution is related to the theory of unemployment insurance. A basic proposition of this literature states that payments should stay constant over time if the unemployed cannot influence their chances of gaining a job. In contrast, if the reemployment opportu- 
nities are determined by unobservable search efforts, expected utility of the beneficiaries is maximized by a declining benefit schedule that converges to zero (Shavell and Weiss, 1979). Hopenhayn and Nicolini (1997) argue that welfare can be further increased in such a moral hazard scenario if the personal wage tax increases with the duration of unemployment. However, Cahuc and Lehmann (2000) show that declining unemployment benefits may even lead to a higher unemployment rate, since insiders will drive up their wage demands when expecting a shorter period of unemployment upon losing their job. Fredriksson and Holmlund (2001) demonstrate within an equilibrium search model that the optimum time limit for receiving the higher benefit in a two tier unemployment insurance system is always positive and finite. The optimum time limit exceeds zero because the search effort of those receiving the smaller benefit increases in the duration of the full benefit. Hassler and Rodriguez Mora (2002) argue that unemployment benefits should even increase over time if the insurer cannot observe consumption and savings. Individuals then prefer to finance short spells of unemployment by precautionary savings.

The remainder of the paper is organized as follows. After introducing the model in section 2, section 3 analyzes problems of existence and stability of equilibria. Comparative static results are derived in section 4 . Section 5 deals with the possibility that employers discriminate against food stamp recipients. The concluding section 6 discusses the findings and indicates directions for future research.

\section{The basic model}

The model is based on Shapiro and Stiglitz (1984). We consider $N$ identical workers whose preferences are described by the utility function $U(\omega, e)=\omega-e$, where $\omega$ denotes the monetary compensation and $e$ is the effort exerted at the workplace. With probability $b$ per unit of time, an employment relationship breaks down for exogenous reasons. Workers are infinitely lived and maximize $W=E \int_{0}^{\infty} U(\omega(s), e(s)) \exp (-r s) d s$, where $s$ denotes time, $r>0$ is the discount rate, and $E$ represents the expectations operator. Any 
employed worker can either shirk $(e=0)$ or choose the required effort $(e=1)$. Workers who are shirking are detected with probability $q$ per unit of time. Detected shirkers are fired immediately. All individuals are identical with respect to ability and preferences. We ignore all issues arising from savings and means tests to qualify for a welfare program.

The unemployed receive a welfare benefit $\bar{w}$ before the time limit is exhausted, while the others get $\underline{w}$, where $\bar{w}>\underline{w} \geq 0$. The lower benefit may represent a food stamp program, while the higher benefit is meant to provide a minimum income above the physical subsistence level. Welfare is financed by a proportional tax on wages and profits, the tax rate being $t$.

Let $V_{E}^{S}, V_{E}^{N}$, and $V_{u}$ denote expected lifetime utility of employed shirkers, employed non-shirkers, and unemployed individuals receiving the full amount of welfare benefits, respectively. The asset equations for shirkers and non-shirkers are given by

$$
r V_{E}^{S}=(1-t) w+(b+q)\left(V_{u}-V_{E}^{S}\right)
$$

and

$$
r V_{E}^{N}=(1-t) w-e+b\left(V_{u}-V_{E}^{N}\right)
$$

with $w$ denoting the gross wage.

The asset equations have the structure that the return in a given period is equal to the flow benefits plus the expected change of the value of the asset. An employed worker will not shirk if $V_{E}^{S} \leq V_{E}^{N}$, which is equivalent to

$$
(1-t) w \geq r V_{u}+\frac{(r+b+q) e}{q}
$$

the no-shirking condition. If workers were risk averse, a lower wage as the one given in (3) would be sufficient to induce effort. Such a modification would, however, not lead to substantially different outcomes.

Firms are operating under decreasing returns. Output of the representative firm is given by $Q=F(L)$ where $L$ denotes effective labor, i.e. the number of employed workers 
not shirking. The production function satisfies $F^{\prime}(L)>0, F^{\prime \prime}(L)<0$ and $F^{\prime}(N)>e$. The last assumption implies that full employment would be efficient.

An unemployed worker receiving benefit $\bar{w}$ will get a job with probability $a_{u}$ per unit of time. Rather than introducing a fixed time limit, the loss of the full benefit is modeled in a stochastic fashion. In a given period, the access to regular benefits is lost with probability $h$. The hazard rate $h$ corresponds to an expected time limit and is seen as a policy variable. If $h=0$, there is no time limit on welfare use. The asset equation of an unemployed worker receiving regular benefits is

$$
r V_{u}=\bar{w}+a_{u}\left(V_{E}-V_{u}\right)+h\left(V_{z}-V_{u}\right)
$$

with $V_{E}=\max \left\{V_{E}^{S}, V_{E}^{N}\right\}$, and $V_{z}$ denotes expected lifetime utility of a welfare recipient in the food stamp program. An individual receiving the reduced benefit faces a probability of reentering employment of $a_{z}=k a_{u}$ per period, where $0<k \leq 1$. The upper boundary $k=1$ corresponds to a situation in which employers do not discriminate against food stamp recipients. In contrast, $k<1$ is the more realistic scenario in which firms are reluctant to hire long-term unemployed. In the basic model, we assume that $k=1$ and set $a=a_{u}=a_{z}$. The case of discrimination is discussed in section 5 . The asset equation of a food stamp recipient reads

$$
r V_{z}=\underline{w}+a\left(V_{E}-V_{z}\right)
$$

If not shirking is optimal, (2), (4), and (5) can be solved. Combining (4) and (5) yields

$$
(r+h+a)\left(V_{u}-V_{z}\right)=\bar{w}-\underline{w},
$$

and subtracting (4) from (2) leads to

$$
(r+b+a)\left(V_{E}-V_{u}\right)=(1-t) w-e-\bar{w}+h\left(V_{u}-V_{z}\right) .
$$

Solving the last two equations for the lifetime utility differentials, it turns out that

$$
V_{E}-V_{u}=\frac{(1-t) w-e-\frac{(r+a) \bar{w}+h \underline{w}}{r+h+a}}{r+a+b},
$$




$$
V_{u}-V_{z}=\frac{\bar{w}-\underline{w}}{r+h+a}
$$

This implies

$$
\begin{gathered}
r V_{u}=\frac{a}{r+a+b}[(1-t) w-e]+\frac{r+b}{r+b+a} \frac{(r+a) \bar{w}+h \underline{w}}{r+h+a}, \\
r V_{E}=\frac{r+a}{r+a+b}[(1-t) w-e]+\frac{b}{r+b+a} \frac{(r+a) \bar{w}+h \underline{w}}{r+h+a}, \\
r V_{z}=\frac{r \underline{w}+a r V_{E}}{r+a} .
\end{gathered}
$$

Inserting (10) into the no-shirking condition yields

$$
(1-t) w \geq \frac{r+a+b+q}{q} e+\frac{(r+a) \bar{w}+h \underline{w}}{r+h+a} .
$$

Inducing workers not to shirk requires a higher wage $w$ if either of the welfare benefits, $\bar{w}$ or $\underline{w}$, rises, the rate of exogenous splits $b$ increases, the rate of obtaining a new job a goes up, the tax rate $t$ increases, the rate of time preference $r$ rises, or the quality of monitoring effort, measured by q, falls. Equations (8) and (13) imply that employed workers will display a higher expected remaining lifetime utility than those being unemployed at any given point in time. Thus, unemployment is involuntary. Compared to those receiving:

full benefits $\bar{w}$, employed workers earn the information rent $\frac{e}{q}$. The rent arises due to the fact that the monitoring technology is imperfect, that is, $q$ is finite.

In equilibrium, the number of entries into unemployment must be equal to the number of exits:

$$
a(N-L)=b L
$$

Similarly, the number of entries into the food stamp program has to be equal to the number of exits:

$$
a(N-L-U)=h U
$$

While $U$ individuals receive regular benefits, $N-L-U$ individuals participate in the food stamp program. Last, the number of entrants into regular social assistance is equal to the number of leavers:

$$
b L=(a+h) U
$$


As $a=b \frac{L}{N-L}$, substituting for $a$ from (14) into (13) leads to

$$
(1-t) w \geq \frac{(r+q)(N-L)+b N}{q(N-L)} e+\frac{(r(N-L)+b L) \bar{w}+h(N-L) \underline{w}}{(r+h)(N-L)+b L} .
$$

Welfare benefits are financed through a proportional income tax $t$ on profits and labour income. The tax base is, therefore, equal to total output $F(L)$, implying that the government budget equation reads

$$
t F(L)=\bar{w} U+\underline{w}(N-L-U) .
$$

If workers do not shirk, the representative firm will set its labor input to the point where the marginal product of labor is equal to the gross wage, that is, where $w=F^{\prime}(L)$. Utilizing this relationship and building on (14) and (16), $U=\frac{b L(N-L)}{b L+h(N-L)}$ shows that feasible allocations require

$$
(1-t) w=F^{\prime}(L)\left[1-\frac{b L \bar{w}+h(N-L) \underline{w}}{b L+h(N-L)} \frac{(N-L)}{F(L)}\right] .
$$

All relevant decisions are taken simultaneously. The government always adjusts the income tax rate instantaneously so as to balance its budget. Firms generally take as given both the wage and the tax rate and choose employment in order to maximize their profits. They are willing to accept underbidding by unemployed workers as long as net wages are higher than necessary to satisfy the no-shirking constraint. Conversely, should the net wage be too low to prevent shirking, firms will increase the gross wage. Taking as given wages, policy variables and the unemployment rate, employed workers choose whether or not to shirk.

\section{Equilibria and stability}

An equilibrium is described by a level of employment that satisfies both the no-shirking: condition (17), now with equality, and the feasibility condition (19). The right-hand side 
of the no-shirking condition (17) is equal to $\frac{r+b+q}{q} e+\frac{r \bar{w}+h \underline{w}}{r+h}>0$ at $L=0$. It increases in $L$ and tends to infinity if $L \rightarrow N$. Note that the right-hand side of the feasibility condition (19) will be equal to $F^{\prime}(N)>0$ if $L=N$. Moreover, provided that $F(0)=0$, an employment level $L_{0} \in(0, N)$ exists which satisfies

$$
\left[1-\frac{b L \bar{w}+h(N-L) \underline{w}}{b L+h(N-L)} \frac{(N-L)}{F(L)}\right]=0 \text {. }
$$

Figure 1 illustrates the equilibrium conditions. The no-shirking condition holds on and above the $N S C$ curve, while the feasibility curve $G$ represents the budget constraint of the government combined with the marginal productivity rule of pay. If the two curves intersect, and if we neglect the possibility of a tangent point, at least two equilibria exist.

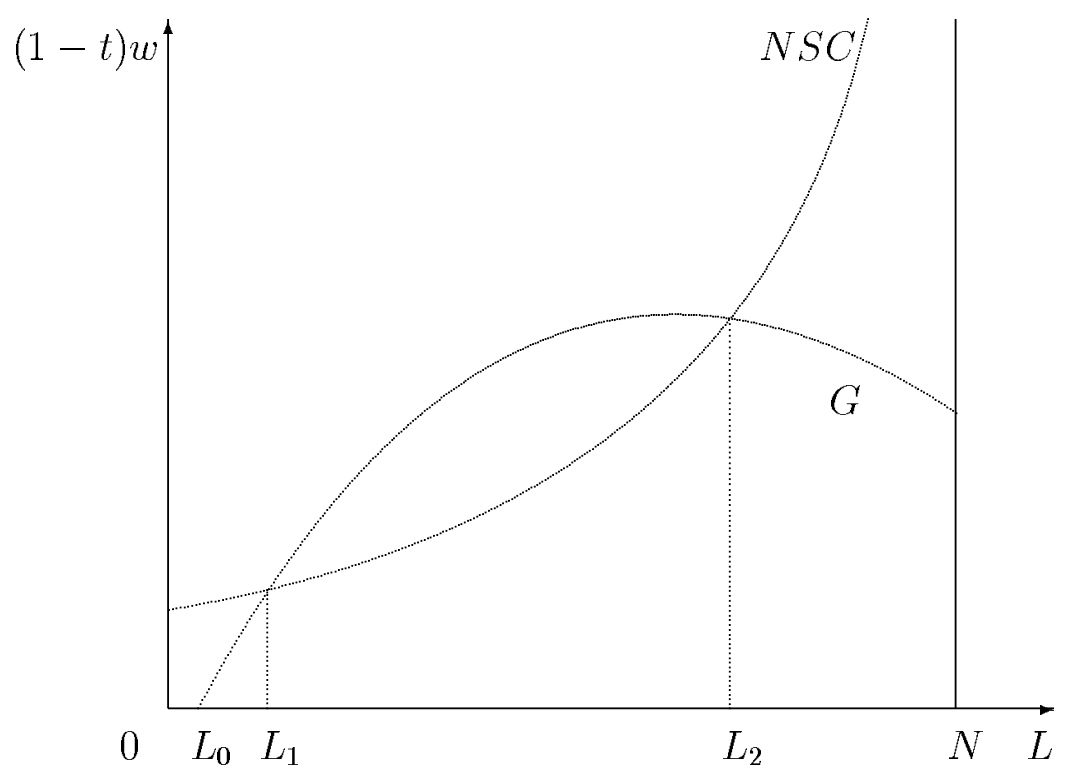

Figure 1. Equilibria. 
In Figure 1, the equilibrium $L_{1}$ is unstable. Should a point on the $G$ curve between $L_{1}$ and $L_{2}$ be realized, the firm is willing to accept underbidding by unemployed workers. As a consequence, employment will increase and the gross wage rate will fall. Underbidding: will no longer be accepted at $L_{2}$ since the no-shirking condition would then be violated.

Rewriting (17) (with equality) and (19) shows that an equilibrium has to satisfy

$$
\begin{aligned}
f_{1}((1-t) w, L)= & (1-t) w-\frac{r+q}{q} e-\frac{b N}{q(N-L)} e \\
& -\frac{(r(N-L)+b L) \bar{w}+h(N-L) \underline{w}}{(r+h)(N-L)+b L} \\
f_{2}((1-t) w, L)= & (1-t) w-F^{\prime}(L)\left[1-\frac{b L \bar{w}+h(N-L) \underline{w}}{b L+h(N-L)} \frac{N-L}{F(L)}\right] .
\end{aligned}
$$

where $f_{1}=f_{2}=0$. Notice that $\frac{\partial f_{1}}{\partial L} \leq \frac{\partial f_{2}}{\partial L}$ is a necessary condition for stability. In a stable equilibrium, the NSC curve cuts the $G$ curve from below.

\section{Changing the benefit loss rate}

Proposition 1 summarizes the effects of an increasing risk of losing the full welfare benefit and having to rely on a food stamp program.

Proposition 1 Employment $L$ increases and the gross wage $w$ decreases with a higher benefit loss rate (that is, a tighter time limit) h. The lifetime utility differential between employed workers and recipients of social assistance, $V_{E}-V_{u}$, remains constant. The lifetime utility differential between social assistance recipients and participants in the food stamp program, $V_{u}-V_{z}$, shrinks. Lifetime utility levels of employed workers and social assistance recipients move in the same direction as the net wage.

Proof. See Appendix A.

The comparative statics can be interpreted as follows. A higher benefit loss rate is equivalent to a stricter time limit of receiving welfare benefits. As a consequence, the 
threat of unemployment becomes more severe. The minimum wage needed to induce effort at the workplace decreases, which corresponds to shifting the NSC curve downwards. Due to a higher share of food stamp recipients at a given level of unemployment, the tax burden decreases. The feasibility curve $G$ shifts upwards for any positive unemployment level. Any gross wage now corresponds to a higher net wage. The tax reduction thus represents a second channel allowing to cut wages and increase employment.

The unemployed are hurt by the loss in expected benefits. At the same time, their job opportunities become better. Moreover, their net wage changes once they reenter employment. For employed workers, the threat of unemployment is more serious now due to stricter time limit for receiving the full benefit. At the same time, the increasing: opportunities of regaining employment work in the opposite direction. In any case, they are also confronted with a variation in their net wage. It turns out that the lifetime utility differental between employed workers and those receiving social assistance remains unchanged, while the net impact on per period utility for each of these groups is determined by the variation in net wages. Employed workers and social assistance recipients are affected symmetrically because the no-shirking condition dictates that the utility differential is exclusively determined by the effort level at the workplace and the quality of the detection technology. The impact of the stricter time limit on food stamp recipients is more positive. In the model, it takes two transitions, into and out of employment, before the time limit can bite. Food stamp recipients thus benefit from better opportunities to leave unemployment and, as forward-looking agents, are also affected by the change in net wages. Their relative utility position compared to the other two groups of workers improves in terms of absolute utility differentials.

Tedius computations provided in Appendix B show the reaction of the equilibrium tax rate to a rising benefit loss rate. The outcome is not obvious because the fall in unemployment will be associated with a smaller share of food stamp recipients among the unemployed. While being quite implausible, an increase in total welfare benefits via 
a rising number of high benefit recipients cannot be excluded. It is demonstrated that the equilibrium tax rate will fall if either the discount rate or the benefit loss rate is sufficiently small. Therefore, we ignore the possibility of a perverse tax reaction in the following.

Firms take advantage of the lower gross wage and the lower tax rate. Their net profits must increase according to

$$
\frac{\partial \pi_{n}}{\partial h}=-\left[F(L)-L F^{\prime}(L)\right] \frac{\partial t}{\partial h}-(1-t) L F^{\prime \prime}(L) \frac{\partial L}{\partial h} .
$$

The impact on the net wage,

$$
\begin{aligned}
\operatorname{sgn} \frac{\partial[(1-t) w]}{\partial h}= & -\operatorname{sgn}\left[f_{1 h} f_{2 L}-f_{2 h} f_{1 L}\right] \\
= & \operatorname{sgn}\left[-\frac{F^{\prime}(L)(N-L)(\bar{w}-\underline{w})}{F(L)} \frac{b L(N-L)}{(h(N-L)+b L)^{2}}\right. \\
& \cdot[-1] \frac{b N}{(N-L)^{2}}\left[\frac{e}{q}+\frac{(N-L)^{2} h(\bar{w}-\underline{w})}{[(r+h)(N-L)+b L]^{2}}\right] \\
& -\frac{(\bar{w}-\underline{w})(r(N-L)+b L)(N-L)}{((r+h)(N-L)+b L)^{2}} \\
& \cdot\left[-F^{\prime \prime}(L)\left[1-\frac{b L \bar{w}+h(N-L) \underline{w}}{b L+h(N-L)} \frac{N-L}{F(L)}\right]\right. \\
& -F^{\prime}(L)\left[\frac{b L \bar{w}+h(N-L) \underline{w} F(L)+(N-L) F^{\prime}(L)}{b L+h(N-L)}\right. \\
& \left.\left.\left.-\frac{(\bar{w}-\underline{w}) h b N}{(h(N-L)+b L)^{2}} \frac{N-L}{F(L)}\right]\right]\right],
\end{aligned}
$$

is ambiguous in general and mainly depends on properties of the production function and the cost of a welfare recipient. If the marginal product of labor responds to a higher labor input in an unelastic fashion $\left(F^{\prime \prime}(L)\right.$ close to zero), the tax reduction is the dominant effect, implying a rise in net wages. Conversely, if the change in the marginal product of labor is stronger, while $\bar{w}$ is small, the overall effect will go in the opposite direction.

Interestingly, the share of food stamp recipients among the unemployed does not necessarily increase. According to equation (15), the ratio between individuals with regular benefits and food stamp recipients is equal to $\frac{U}{N-L-U}=\frac{a}{h}$. While a stricter time 
limit (higher $h$ ) directly induces a higher share of food stamp recipients, the resulting: higher employment level is associated with a rising job acquisition rate $a$. The latter effect reduces the number and the share of those losing the full welfare benefit. Hence, if the increase in employment is so strong that the elasticity $\eta_{a, h}:=\frac{h}{a} \frac{\partial a}{\partial h}$ exceeds one, a smaller share of food stamp recipients among the unemployed will turn out. This is illustrated by an example presented in Appendix C.

Should net wages fall, it may still be the case that introducing time limits wins a political majority. First, the residual income, which can be interpreted as capital income, increases. Provided there is a sufficiently even distribution of wealth, losses in workers' expected utility may be offset by gains in capital income. Second, workers may take into account that there is a higher chance to be among the employed in this framework. A worker taking decisions behind a veil of ignorance - that is, not knowing the realization of his employment status - may opt for the stricter time limit even if this is associated with a utility reduction under all possible employment states. In fact, the higher total production outweighs the additional effort of the workers. With risk-neutral agents deciding under a veil of ignorance, this property calls for abolishing regular social assistance. However, it should be noted that the probability of having to face the least fortunate state of a food stamp recipient will often increase. If workers are risk averse, a utilitarian government will therefore typically not simply set the time limit to zero.

With the veil of ignorance removed, the outcome can be reversed. A Pareto improvement may even not be achieved by taxing capital on a lump-sum basis and redistributing: the proceeds equally among the workers. Note that this type of redistribution does not affect incentives in the model. Yet, as the share of workers enjoying the highest utility level increases, capital owners and both employed and unemployed workers may lose after redistribution has taken place in such a setting. 


\section{Discrimination}

Employers are often reluctant to hire individuals who are long-term unemployed or food stamp recipients. Such a behavior can be justified if unemployment causes a depreciation of human capital or if a long duration of unemployment is informative as a signal for a possible low quality of the worker. Of course, preferring short-term unemployed job seekers can also be a sign of discrimination which is costless to the firm if labor supply is homogenous. This latter aspect is incorporated into the model as follows.

In each period of time, an individual receiving the reduced amount of benefits faces a probability of reentering employment of $a_{z}=k a_{u}$, where $0<k<1$. The asset equation of a food stamp recipient now reads

$$
r V_{z}=\underline{w}+a_{z}\left(V_{E}-V_{z}\right) .
$$

If not shirking is optimal, (2), (4), and (22) can be solved. Combining (4) and (22) yields

$$
\left(r+h+k a_{u}\right)\left(V_{u}-V_{z}\right)=\bar{w}-\underline{w}+(1-k) a_{u}\left(V_{E}-V_{u}\right),
$$

and subtracting (4) from (2) leads to

$$
\left(r+b+a_{u}\right)\left(V_{E}-V_{u}\right)=(1-t) w-e-\bar{w}+h\left(V_{u}-V_{z}\right) .
$$

Solving the last two equations for the lifetime utility differentials, it turns out that

$$
\begin{gathered}
V_{E}-V_{u}=\frac{(1-t) w-e-\frac{\left(r+k a_{u}\right) \bar{w}+h \underline{w}}{r+k a_{u}+h}}{r+b+a_{u} \frac{r+k a_{u}+k h}{r+k a_{u}+h}}, \\
V_{u}-V_{z}=\frac{\bar{w}-\underline{w}}{r+k a_{u}+h}+\frac{(1-k) a_{u}}{r+k a_{u}+h} \cdot \frac{(1-t) w-e-\frac{\left(r+k a_{u}\right) \bar{w}+h \underline{w}}{r+k a_{u}+h}}{r+b+a_{u} \frac{r+k a_{u}+k h}{r+k a_{u}+h}} .
\end{gathered}
$$

This implies that

$$
r V_{u}=\frac{a_{u}}{a_{u}+(r+b) \psi}[(1-t) w-e]+\frac{(r+b) \psi}{a_{u}+(r+b) \psi} \frac{\left(r+k a_{u}\right) \bar{w}+h \underline{w}}{r+k a_{u}+h}
$$




$$
r V_{E}=\frac{a_{u}+r \psi}{a_{u}+(r+b) \psi}[(1-t) w-e]+\frac{b \psi}{a_{u}+(r+b) \psi} \frac{\left(r+k a_{u}\right) \bar{w}+h \underline{w}}{r+k a_{u}+h}
$$

where $\psi=\frac{r+k a_{u}+h}{r+k a_{u}+k h}$.

$$
r V_{z}=\frac{r \underline{w}+k a_{u} r V_{E}}{r+k a_{u}}
$$

Inserting (27) into the no-shirking condition (3) yields, after rearranging,

$$
(1-t) w \geq e+\frac{\left(r+k a_{u}\right) \bar{w}+h \underline{w}}{r+k a_{u}+h}+\frac{r+b+\frac{a_{u}}{\psi}}{q} e .
$$

If (30) holds with equality, it follows from (25) that $V_{E}-V_{u}=\frac{e}{q}$. As in the basic model, decreasing the time limit does not affect the utility differential between employed workers and recipients of social assistance. Applying the same equality to the other lifetime utility differential, we find that

$$
V_{u}-V_{z}=\frac{\bar{w}-\underline{w}+(1-k) a_{u} \frac{e}{q}}{r+h+k a_{u}} .
$$

As in the baseline case, the equilibrium number of entries into unemployment must be equal to the number of exits:

$$
a_{u}[U+k(N-L-U)]=b L
$$

Further, the number of entries into the food stamp program is equal to the number of exits:

$$
k a_{u}(N-L-U)=h U
$$

Finally, the number of new unemployed is equal to the number of those no longer receiving regular benefits.

$$
b L=\left(a_{u}+h\right) U .
$$

The proportion of the two types of welfare recipients immediately follows from (33), implying that $\frac{N-L-U}{U}=\frac{h}{k a_{u}}$. Hence, the share of food stamp recipients increases 
with a stronger discrimination against long-term unemployed (lower $k$ ), a tighter labor market situation (smaller $a_{u}$ ) and a stricter time limit (higher $h$ ). The equilibrium share of beneficiaries of the food stamp program among all welfare recipients is $\frac{N-L-U}{N-L}$. It is straightforward that

$$
\frac{N-L-U}{N-L}=\frac{h}{k a_{u}+h}
$$

Rewriting equation $(32)$ as $a_{u}[(N-L)-(1-k)(N-L-U)]=b L$, and replacing $(N-L-U)$ from $(35)$ yields

$$
\left[a_{u}-(1-k) \frac{h a_{u}}{h+k a_{u}}\right](N-L)=b L
$$

In the case of discrimination, with $k<1$, this leads to a quadratic equation with respect to $a_{u}$ for a given employment level $L$. However, there is always one negative and one positive root, only the latter being relevant:

$$
a_{u}=\frac{b L-h(N-L)}{2(N-L)}+\sqrt{\left(\frac{b L-h(N-L)}{2(N-L)}\right)^{2}+\frac{b h}{k} \frac{L}{N-L}}
$$

From (36) it follows that

$$
\frac{\partial a_{u}}{\partial h}=\frac{(1-k) \frac{k a_{u}^{2}}{\left(h+k a_{u}\right)^{2}}}{1-(1-k) \frac{h^{2}}{\left(h+k a_{u}\right)^{2}}}>0
$$

and

$$
\frac{\partial a_{u}}{\partial L}=\frac{a_{u}-(1-k) \frac{h a_{u}}{h+k a_{u}}+b}{\left[1-(1-k)\left(\frac{h a_{u}}{h+k a_{u}}\right)^{2}\right](N-L)}>0
$$

As in the basic model, the employment probability $a_{u}$ increases with a higher number of jobs. In the case of discrimination the chances for a social assistance recipient to reenter employment increase with a stricter time limit keeping employment fixed. For a given number of unemployed, a stricter time limit implies that the share of food stamp recipients increases. Since these long-term unemployed are discriminated according to a constant 
factor and the number of exits out of unemployment stays constant, the probability of leaving unemployment must increase for any member of a given group.

Combining the government budget equation,

$$
t F(L)=\bar{w} U+\underline{w}(N-L-U)
$$

with the labor demand equation $w=F^{\prime}(L)$ yields the feasibility condition

$$
\begin{aligned}
(1-t) w & =F^{\prime}(L)\left(1-\frac{(\bar{w}-\underline{w}) U+\underline{w}(N-L)}{F(L)}\right) \\
& =F^{\prime}(L)\left[1-\frac{\bar{w} k a_{u}+h \underline{w}}{k a_{u}+h} \frac{N-L}{F(L)}\right] .
\end{aligned}
$$

With the hazard rate $a_{u}$ given from (37), equation (39) and the aggregate no-shirking condition (30) determine employment $L$ and the net wage $(1-t) w$.

Appendix D shows the impact of increasing the benefit loss rate on employment. There are counteracting forces on the no-shirking curve. On the one hand, unemployment is associated with an increased risk of losing the full benefit. On the other hand, the chances to regain employment increase in both states of unemployment. Thus, it is no longer obvious that unemployment becomes more threatening. Similarly, the tax rate tends to fall due to a smaller share of recipients of the high benefit at given job acquisition rates. However, the rising job acquisition rates change the structure of unemployment in favor of the regular social assistance recipients. The last effect in isolation tends to increase the tax rate. While we cannot show that employment grows in any case, the result holds if the strength of discrimination is sufficiently small.

Proposition 2 shows that the distributional implications are quite similar to the scenario of the basic model.

Proposition 2 Under discrimination of food stamp recipients in the labor market, the lifetime utility differential between employed workers and social assistance recipients, $V_{E}-$ $V_{u}$, remains constant under a stricter time limit. The lifetime utility differential between social assistance recipients and participants in the food stamp program, $V_{u}-V_{z}$, is shrinking 
if employment increases and if $k \geq \widetilde{k}$, where $\widetilde{k}=\frac{(r+h) \frac{e}{q}}{\bar{w}-\underline{w}+(r+h) \frac{e}{q}}$. Lifetime utility of employed workers and social assistance recipients move in the same direction as the net wage.

Proof. Recalling that $V_{E}-V_{u}=\frac{e}{q}$, it immediately follows that a variation in the benefit loss rate leaves the utility differential between employed workers and recipients of social assistance unchanged. With a constant lifetime utility differential, (3) implies that $r \frac{\partial V_{E}}{\partial h}=\frac{\partial(1-t) w}{\partial h}$ turns out. Further, differentiating (31) with respect to $h$ yields

$$
\begin{aligned}
\frac{\partial\left[V_{u}-V_{z}\right]}{\partial h}= & \frac{(r+h)(1-k) \frac{e}{q}-k(\bar{w}-\underline{w})}{\left(r+h+k a_{u}\right)^{2}}\left[\frac{\partial a_{u}}{\partial h}+\frac{\partial a_{u}}{\partial L} \frac{\partial L}{\partial h}\right] \\
& -\frac{\bar{w}-\underline{w}+(1-k) a_{u} \frac{e}{q}}{\left(r+h+k a_{u}\right)^{2}} .
\end{aligned}
$$

Since $\frac{\partial a_{u}}{\partial h}>0, \frac{\partial a_{u}}{\partial L}>0$ and $\frac{\partial L}{\partial h}>0$ hold, the first term is non-positive if and only if $k \geq \widetilde{k}$. This suffices to prove the second claim.

As in the basic model, the utility differential between employed workers and regular social assistance recipients is exclusively determined by the effort level at the workplace and the shirking detection technology. It turns out that discrimination in hiring decisions does not affect the main result: the net change in lifetime utility of employed and short-term unemployed is perfectly correlated with the change in the net wage. While discrimination clearly increases the utility differential between social assistance recipients and participants in the food stamp program, the differential tends to shrink with a tighter time limit.

\section{Conclusions}

The main message of the paper is that changes in the net wage are of particular importance when evaluating the welfare consequences of introducing or tightening time limits in social 
assistance systems. Lifetime utilities of employed and short-term unemployed workers move in the same direction as the net wage, while the poorest long-term unemployed may gain in expected lifetime utility even if employers are reluctant to hire food stamp recipients.

Though unemployment generally falls, the structure of unemployment may in extreme cases display a surprising evolution. The stricter time limit in itself induces a smaller share of recipients of full benefit recipients. At the same time, the rising number of jobs reduces the average duration of unemployment, where the resulting higher share of short-term unemployed can offset the direct effect of the stricter time limit.

Evaluating the aggregate welfare consequences of introducing or tightening time limits on benefit receipts remains difficult due to its distributional implications. While the expected increase in total output bears the potential for a Pareto improvement, a higher share of food stamp recipients is certain when the time limit is introduced, and it will often turn out when the time limit is tightened. On the other hand, the analysis indicates that food stamp recipients are winners of the welfare reform in terms of utility differentials when compared to other workers.

Introducing heterogeneous types of labor represents an extension of the model that may prove useful to shed more light on the distributional implications of varying eligibility rules for welfare recipients. In particular, skilled workers will typically subsidize unskilled workers in the welfare system. Due to their higher productivitiy, the shirking model implies that the unemployment rate of skilled workers falls short of the unemployment rate of unskilled workers. Further, at a given proportional tax rate, the higher wage per worker is mirrored in a higher tax payment. A fall in unemployment reduces the subsidy per employed skilled worker towards the unskilled unemployed. Another effect arises should skilled and unskilled labor be complements in production. In this event, any fall in unemployment of one type of labor raises the productivity of the other type of labor, implying a positive impact on welfare of the other group. 


\section{Appendix}

\section{A: Proof of Proposition 1}

Utilizing the implicit function theorem, it follows for any variable $x \in\{(1-t) w, L\}$ that $\frac{d x}{d h}=-\frac{\Delta_{x h}}{\Delta}$, where $\Delta$ is the determinant of the Jacobian of $(20)$ and (21), and $\Delta_{x h}$ represents the determinant of the corresponding Jacobian in which the column vector $\left(\begin{array}{l}f_{1 x} \\ f_{2 x}\end{array}\right)$ is replaced by $\left(\begin{array}{l}f_{1 h} \\ f_{2 h}\end{array}\right)$. Taking into account the sufficient stability condition $\Delta>0$, and ignoring the case that only the necessary condition is satisfied, it follows that $\operatorname{sgn}\left[\frac{\partial x}{\partial h}\right]=-\operatorname{sgn}\left[\Delta_{x h}\right]$. Evaluating the derivatives reveals that

$$
\begin{aligned}
\operatorname{sgn}\left[\Delta_{L h}\right]= & \operatorname{sgn}\left[f_{2 h}-f_{1 h}\right] \\
= & \operatorname{sgn}\left[-\frac{F^{\prime}(L)(N-L)^{2}(\bar{w}-\underline{w})}{F(L)} \frac{b L}{(h(N-L)+b L)^{2}}\right. \\
& \left.-\frac{(N-L)(\bar{w}-\underline{w})(r(N-L)+b L)}{((r+h)(N-L)+b L)^{2}}\right] \\
< & 0, \\
\frac{\partial w}{\partial h}= & F^{\prime \prime}(L) \frac{\partial L}{\partial h}<0, \\
\frac{\partial\left[V_{E}-V_{u}\right]}{\partial h}= & 0, \\
\frac{\partial\left[V_{u}-V_{z}\right]}{\partial h}= & -\frac{(\bar{w}-\underline{w})\left((N-L)^{2}+b N \frac{\partial L}{\partial h}\right)}{((r+h)(N-L)+b L)^{2}}<0 .
\end{aligned}
$$

Since $\frac{\partial\left[V_{E}-V_{u}\right]}{\partial h}=0$, it follows from $(3)$ that $r \frac{\partial V_{E}}{\partial h}=\frac{\partial(1-t) w}{\partial h}$.

\section{B: Impact on the tax rate}

Calculating the impact of raising the benefit loss rate on the tax rate in the basic model from equation (19), where (14) is taken into account, yields

$$
\begin{aligned}
\frac{\partial t}{\partial h}= & -(\bar{w}-\underline{w}) \frac{a}{[a+h]^{2}} \frac{N-L}{F(L)}+\frac{h(\bar{w}-\underline{w})(b+a)}{[a+h]^{2}} \frac{1}{F(L)} \frac{\partial L}{\partial h} \\
& -\frac{a \bar{w}+h \underline{w}}{a+h} \frac{F(L)+(N-L) F^{\prime}(L)}{[F(L)]^{2}} \frac{\partial L}{\partial h} .
\end{aligned}
$$


The first term on the right-hand side in the first line shows the smaller expenditure level due to the higher share of food stamp recipients at a given unemployment rate. The second term mirrors the change in the structure of unemployment towards a higher share of social assistance recipients with a fall in total unemployment. Finally, the second line indicates the increase of the tax base. Taking into account $\frac{\partial L}{\partial h}=-\frac{f_{2 h}-f_{1 h}}{f_{2 L}-f_{1 L}}$ leads to

$$
\begin{aligned}
\operatorname{sgn}\left[\frac{\partial t}{\partial h}\right]= & \operatorname{sgn}\left[-(\bar{w}-\underline{w}) \frac{a}{[a+h]^{2}} \frac{N-L}{F(L)}\left(f_{2 L}-f_{1 L}\right)\right. \\
& +\left[\frac{[a \bar{w}+h \underline{w}]}{a+h} \frac{F(L)+(N-L) F^{\prime}(L)}{[F(L)]^{2}}\right. \\
& \left.\left.-\frac{h(\bar{w}-\underline{w})(b+a)}{[a+h]^{2}} \frac{1}{F(L)}\right]\left(f_{2 h}-f_{1 h}\right)\right] .
\end{aligned}
$$

It follows that

$$
\begin{aligned}
\operatorname{sgn}\left[\frac{\partial t}{\partial h}\right]= & \operatorname{sgn}\left[-(\bar{w}-\underline{w})(N-L) \frac{a}{[a+h]^{2}}\right. \\
& \cdot\left[-F^{\prime \prime}(L)(1-t)+\frac{b e N}{q(N-L)^{2}}+\frac{h(\bar{w}-\underline{w}) \frac{a+b}{N-L}}{[r+h+a]^{2}}\right. \\
& +\frac{F^{\prime}(L)(\bar{w}-\underline{w})}{F(L)} \frac{h(a+b)}{[h+a]^{2}} \\
& \left.-F^{\prime}(L) \frac{[a \bar{w}+h \underline{w}]}{a+h} \frac{F(L)+(N-L) F^{\prime}(L)}{[F(L)]^{2}}\right] \\
+ & {\left[(\bar{w}-\underline{w}) \frac{h(a+b)}{[a+h]^{2}}-\frac{a \bar{w}+h \underline{w}}{a+h}\left[1+\frac{(N-L) F^{\prime}(L)}{F(L)}\right]\right] } \\
& \left.\cdot\left[\frac{F^{\prime}(L)(N-L)(\bar{w}-\underline{w})}{F(L)} \frac{a}{(h+a)^{2}}+\frac{(\bar{w}-\underline{w})(r+a)}{(r+h+a)^{2}}\right]\right] .
\end{aligned}
$$

Simplifying this expression yields 


$$
\begin{aligned}
\operatorname{sgn}\left[\frac{\partial t}{\partial h}\right]= & \operatorname{sgn}\left[-(N-L) \frac{a}{[a+h]^{2}}\left[-F^{\prime \prime}(L)(1-t)+\frac{b e N}{q(N-L)^{2}}\right]\right. \\
& -\frac{[a \bar{w}+h \underline{w}]}{a+h} \frac{(N-L) F^{\prime}(L)}{F(L)} \frac{(r+a)}{(r+h+a)^{2}} \\
& -\frac{1}{(r+h+a)^{2}[a+h]^{2}}[(a+h)(a \bar{w}+h \underline{w})(r+a) \\
& -r h(a+b)(\bar{w}-\underline{w})]]
\end{aligned}
$$

and

$$
\begin{aligned}
\operatorname{sgn}\left[\frac{\partial t}{\partial h}\right]= & \operatorname{sgn}\left[-(N-L) \frac{a}{[a+h]^{2}}\left[-F^{\prime \prime}(L)(1-t)+\frac{b e N}{q(N-L)^{2}}\right]\right. \\
& -\frac{[a \bar{w}+h \underline{w}]}{a+h} \frac{(N-L) F^{\prime}(L)}{F(L)} \frac{(r+a)}{(r+h+a)^{2}} \\
& -\frac{1}{(r+h+a)^{2}[a+h]^{2}}[a(a+h)(a \bar{w}+h \underline{w}) \\
& \left.\left.+r\left[(a+h)^{2} \underline{w}+\left(a^{2}-h b\right)(\bar{w}-\underline{w})\right]\right]\right] .
\end{aligned}
$$

It follows that $\frac{\partial t}{\partial h}<0$ if either the discount rate $r$ or the benefit loss rate $h$ is sufficiently close to zero.

\section{C: Example with falling share of food stamp recipients}

Assume a production function with diminishing marginal returns $p L^{\alpha}+3 L$ with the parameter values $p=10000$ and $\alpha=.001$, a population of $N=1000$, an interest rate of $r=.04$, required effort of $e=0.1$, a separation rate of $b=.01$, a detection probability of $q=0.9$, social assistance of $\bar{w}=1$ and food stamp payment of $\underline{w}=0.1$. For the corresponding benefit loss rate $h$ given in Table 1 we compute the stable employment level and the ratio of regular benefit recipients to food stamp recipients. 


$$
\begin{array}{ccc}
h & L & a / h \\
1 & 250.61 & 3.3442 \times 10^{-3} \\
0.8 & 211.23 & 3.3475 \times 10^{-3} \\
0.6 & 166.57 & 3.3310 \times 10^{-3} \\
0.4 & 117.50 & 3.3286 \times 10^{-3} \\
0.2 & 65.267 & 3.4912 \times 10^{-3}
\end{array}
$$

Table 1. Impact on structure of welfare recipients.

It turns out that the share of regular social assistance recipients falls when increasing the benefit loss rate from .2 to .4 . The opposite reaction occurs when increasing this rate from .4 to .8 .

\section{D: Impact on employment under discrimination}

Notice that the equilibrium $((1-t) w, L)$ is determined by the two equations

$$
\begin{aligned}
f_{d 1} & =(1-t) w-e-\frac{\left(r+k a_{u}\right) \bar{w}+h \underline{w}}{r+k a_{u}+h}-\frac{r+b+a_{u} \frac{r+k a_{u}+k h}{r+k a_{u}+h}}{q} e, \\
f_{d 2} & =(1-t) w-F^{\prime}(L)\left[1-\frac{k a_{u} \bar{w}+h \underline{w}}{h+k a_{u}} \frac{N-L}{F(L)}\right],
\end{aligned}
$$

with $f_{d 1}=f_{d 2}=0$ where $a_{u}(L, h)$. Stability requires $f_{d 2 L}-f_{d 1 L}>0$. According to the implicit function theorem, the impact on employment is given by $\frac{\partial L}{\partial h}=-\frac{f_{d 2 h}-f_{d 1 h}}{f_{d 2 L}-f_{d 1 L}}$. Evaluating the numerator yields

$$
\begin{aligned}
f_{d 2 h}-f_{d 1 h}= & \frac{F^{\prime}(L)(N-L)(\bar{w}-\underline{w})}{F(L)} \frac{h k \frac{\partial a_{u}}{\partial h}-k a_{u}}{\left[h+k a_{u}\right]^{2}} \\
& -(\bar{w}-\underline{w}) \frac{r+k a_{u}-h k \frac{\partial a_{u}}{\partial h}}{\left[r+h+k a_{u}\right]^{2}}+\frac{e}{q} \frac{\partial a_{u}}{\partial h} \\
& -\frac{e}{q}(1-k) \frac{r\left[a_{u}+h \frac{\partial a_{u}}{\partial h}\right]+h^{2} \frac{\partial a_{u}}{\partial h}+k a_{u}^{2}}{\left[r+h+k a_{u}\right]^{2}} .
\end{aligned}
$$


Since $\frac{\partial a_{u}}{\partial h}=\frac{(1-k) a_{u}^{2}}{h^{2}+2 h a_{u}+k a_{u}^{2}}<\frac{a_{u}}{h}$ is valid, the first two terms are negative. The two other terms tend to zero for $k \rightarrow 1$. The sign of these two terms is given by $\operatorname{sgn}\left[\left[r+k a_{u}\right] a_{u}-h\left[h+(1-k) a_{u}\right]\right]$, which is positive for $h$ sufficiently small. 


\section{References}

Arulampalam, W. and M. B. Stewart. (1995). "The Determinants of Individual Unemployment Durations in an Era of High Unemployment." Economic Journal 105, $321-332$.

Blank, R. M. (2002). "Evaluating Welfare Reform in the United States." Journal of Economic Literature 40, 1105-1166.

Cahuc, P. and E. Lehmann. (2000). "Should Unemployment Benefits Decrease with the Unemployment Spell?" Journal of Public Economics 77, 135-153.

Duncan, G. J., K. M. Harris, and J. Boisjoly. (2000). "Time Limits and Welfare Reform: New Estimates of the Number and Characteristics of Affected Families." Social Service Review 74, 55-75.

Ellwood, D. T. (2000). "Anti-Poverty Policy for Families in the Next Century: From Welfare to Work - and Worries." Journal of Economic Perspectives 14, 187-198.

Fredriksson, P. and B. Holmlund. (2001). "Optimal Unemployment Insurance in Search Equilibrium." Journal of Labor Economics 19, 370-399.

Gittleman, M. (1999). "Time Limits on Welfare Receipt." Contemporary Economic Policy 17, 199-209.

Hassler, J. and J. V. Rodriguez Mora. (2002). "Should UI Benefits Really Fall over Time?" CESifo Working Paper No. 804, Munich.

Haveman, R. and B. Wolfe. 2000. "Welfare to Work in the U.S.: A Model for Other Developed Nations?" International Tax and Public Finance 7, 95-114.

Hopenhayn, H. A. and J. P. Nicolini. (1997). "Optimal Unemployment Insurance." Journal of Political Economy 105, 412-438. 
Hotz, V. J., C. H. Mullin and J. K. Scholz. (2002). "Welfare, Employment and Income: Evidence on the Effects of Benefit Reduction from California." American Economic Review, Papers and Proceedings 92, 380-384.

Moffitt, R. A. (2002). "The Temporary Assistance for Needy Families Program." NBER Working Paper No. 8749, Cambridge.

Shapiro, C. and J. E. Stiglitz (1984). "Equilibrium Unemployment as a Worker Discipline Device." American Economic Review 74, 433-444.

Shavell, S. and L. Weiss. (1979). "The Optimal Payment of Unemployment Insurance Benefits over Time." Journal of Political Economy 87, 1347-1362.

Ziliak, J. P., D. N. Figlio, E. E. Davis and L. S. Conolly. (2000). "Accounting for the Decline in AFDC Caseloads: Welfare Reform or the Economy?" Journal of Human Resources 35, 570-586. 


\section{CESifo Working Paper Series}

(for full list see www.cesifo.de)

1156 George Economides, Sarantis Kalyvitis, and Apostolis Philippopoulos, Do Foreign Aid Transfers Distort Incentives and Hurt Growth? Theory and Evidence from 75 Aidrecipient Countries, March 2004

1157 Robert Fenge and Volker Meier, Are Family Allowances and Fertility-related pensions Siamese Twins?, March 2004

1158 Bruno S. Frey, Simon Luechinger, and Alois Stutzer, Valuing Public Goods: The Life Satisfation Approach, March 2004

1159 Jerome L. Stein and Guay C. Lim, Asian Crises: Theory, Evidence, Warning-Signals, March 2004

1160 Romain Ranciere, Aaron Tornell, and Frank Westermann, Crises and Growth: A ReEvaluation, March 2004

1161 Assaf Razin and Efraim Sadka, Transparency, Specialization and FDI, March 2004

1162 Ludger Woessmann, How Equal Are Educational Opportunities? Family Background and Student Achievement in Europe and the United States, March 2004

1163 B.M.S. van Praag and Barbara E. Baarsma, Using Happiness Surveys to Value Intangibles: The Case of Airport Noise, March 2004

1164 Aaron Tornell, Frank Westermann, and Lorenza Martínez, The Positive Link Between Financial Liberalization, Growth, and Crises, March 2004

1165 Helge Berger and Carsten Hefeker, One Country, One Vote? Labor Market Structure and Voting Rights in the ECB, March 2004

1166 Clemens Fuest and Martin Kolmar, A Theory of User-Fee Competition, March 2004

1167 Friedrich Schneider and Robert Klinglmair, Shadow Economies around the World: What Do We Know?, April 2004

1168 Horst Raff and Nicolas Schmitt, Exclusive Dealing and Common Agency in International Markets, April 2004

1169 M. Hashem Pesaran and Allan Timmermann, Real Time Econometrics, April 2004

1170 Sean D. Barrett, Privatisation in Ireland, April 2004 
1171 V. Anton Muscatelli, Patrizio Tirelli and Carmine Trecroci, Can Fiscal Policy Help Macroeconomic Stabilisation? Evidence from a New Keynesian Model with Liquidity Constraints, April 2004

1172 Bernd Huber and Marco Runkel, Tax Competition, Excludable Public Goods and User Charges, April 2004

1173 John McMillan and Pablo Zoido, How to Subvert Democracy: Montesinos in Peru, April 2004

1174 Theo Eicher and Jong Woo Kang, Trade, Foreign Direct Investment or Acquisition: Optimal Entry Modes for Multinationals, April 2004

1175 Chang Woon Nam and Doina Maria Radulescu, Types of Tax Concessions for Attracting Foreign Direct Investment in Free Economic Zones, April 2004

1176 M. Hashem Pesaran and Andreas Pick, Econometric Issues in the Analysis of Contagion, April 2004

1177 Steinar Holden and Fredrik Wulfsberg, Downward Nominal Wage Rigidity in Europe, April 2004

1178 Stefan Lachenmaier and Ludger Woessmann, Does Innovation Cause Exports? Evidence from Exogenous Innovation Impulses and Obstacles, April 2004

1179 Thiess Buettner and Johannes Rincke, Labor Market Effects of Economic Integration The Impact of Re-Unification in German Border Regions, April 2004

1180 Marko Koethenbuerger, Leviathans, Federal Transfers, and the Cartelization Hypothesis, April 2004

1181 Michael Hoel, Tor Iversen, Tore Nilssen, and Jon Vislie, Genetic Testing and Repulsion from Chance, April 2004

1182 Paul De Grauwe and Gunther Schnabl, Exchange Rate Regimes and Macroeconomic Stability in Central and Eastern Europe, April 2004

1183 Arjan M. Lejour and Ruud A. de Mooij, Turkish Delight - Does Turkey's accession to the EU bring economic benefits?, May 2004

1184 Anzelika Zaiceva, Implications of EU Accession for International Migration: An Assessment of Potential Migration Pressure, May 2004

1185 Udo Kreickemeier, Fair Wages and Human Capital Accumulation in a Global Economy, May 2004

1186 Jean-Pierre Ponssard, Rent Dissipation in Repeated Entry Games: Some New Results, May 2004

1187 Pablo Arocena, Privatisation Policy in Spain: Stuck Between Liberalisation and the Protection of Nationals' Interests, May 2004 
1188 Günter Knieps, Privatisation of Network Industries in Germany: A Disaggregated Approach, May 2004

1189 Robert J. Gary-Bobo and Alain Trannoy, Efficient Tuition Fees, Examinations, and Subsidies, May 2004

1190 Saku Aura and Gregory D. Hess, What's in a Name?, May 2004

1191 Sjur Didrik Flåm and Yuri Ermoliev, Investment Uncertainty, and Production Games, May 2004

1192 Yin-Wong Cheung and Jude Yuen, The Suitability of a Greater China Currency Union, May 2004

1193 Inés Macho-Stadler and David Pérez-Castrillo, Optimal Enforcement Policy and Firms' Emissions and Compliance with Environmental Taxes, May 2004

1194 Paul De Grauwe and Marianna Grimaldi, Bubbles and Crashes in a Behavioural Finance Model, May 2004

1195 Michel Berne and Gérard Pogorel, Privatization Experiences in France, May 2004

1196 Andrea Galeotti and José Luis Moraga-González, A Model of Strategic Targeted Advertising, May 2004

1197 Hans Gersbach and Hans Haller, When Inefficiency Begets Efficiency, May 2004

1198 Saku Aura, Estate and Capital Gains Taxation: Efficiency and Political Economy Consideration, May 2004

1199 Sandra Waller and Jakob de Haan, Credibility and Transparency of Central Banks: New Results Based on Ifo's World Economicy Survey, May 2004

1200 Henk C. Kranendonk, Jan Bonenkamp, and Johan P. Verbruggen, A Leading Indicator for the Dutch Economy - Methodological and Empirical Revision of the CPB System, May 2004

1201 Michael Ehrmann, Firm Size and Monetary Policy Transmission - Evidence from German Business Survey Data, May 2004

1202 Thomas A. Knetsch, Evaluating the German Inventory Cycle - Using Data from the Ifo Business Survey, May 2004

1203 Stefan Mittnik and Peter Zadrozny, Forecasting Quarterly German GDP at Monthly Intervals Using Monthly IFO Business Conditions Data, May 2004

1204 Elmer Sterken, The Role of the IFO Business Climate Indicator and Asset Prices in German Monetary Policy, May 2004 
1205 Jan Jacobs and Jan-Egbert Sturm, Do Ifo Indicators Help Explain Revisions in German Industrial Production?, May 2004

1206 Ulrich Woitek, Real Wages and Business Cycle Asymmetries, May 2004

1207 Burkhard Heer and Alfred Maußner, Computation of Business Cycle Models: A Comparison of Numerical Methods, June 2004

1208 Costas Hadjiyiannis, Panos Hatzipanayotou, and Michael S. Michael, Pollution and Capital Tax Competition within a Regional Block, June 2004

1209 Stephan Klasen and Thorsten Nestmann, Population, Population Density, and Technological Change, June 2004

1210 Wolfgang Ochel, Welfare Time Limits in the United States - Experiences with a New Welfare-to-Work Approach, June 2004

1211 Luis H. R. Alvarez and Erkki Koskela, Taxation and Rotation Age under Stochastic Forest Stand Value, June 2004

1212 Bernard M. S. van Praag, The Connexion Between Old and New Approaches to Financial Satisfaction, June 2004

1213 Hendrik Hakenes and Martin Peitz, Selling Reputation When Going out of Business, June 2004

1214 Heikki Oksanen, Public Pensions in the National Accounts and Public Finance Targets, June 2004

1215 Ernst Fehr, Alexander Klein, and Klaus M. Schmidt, Contracts, Fairness, and Incentives, June 2004

1216 Amihai Glazer, Vesa Kanniainen, and Panu Poutvaara, Initial Luck, Status-Seeking and Snowballs Lead to Corporate Success and Failure, June 2004

1217 Bum J. Kim and Harris Schlesinger, Adverse Selection in an Insurance Market with Government-Guaranteed Subsistence Levels, June 2004

1218 Armin Falk, Charitable Giving as a Gift Exchange - Evidence from a Field Experiment, June 2004

1219 Rainer Niemann, Asymmetric Taxation and Cross-Border Investment Decisions, June 2004

1220 Christian Holzner, Volker Meier, and Martin Werding, Time Limits on Welfare Use under Involuntary Unemployment, June 2004 